\title{
Comparison of Learning Outcomes Inquiry Learning Model With Cooperative Learning Model Type Number Head Together (NHT) Learning In Natural Sciences Class V In State Elementary School 66 Bengkulu City
}

\author{
Rohimin'1, Wiji Aziz Hari Mukti², Septa Oktaviani ${ }^{3}$, Muhammad Erfan ${ }^{4}$, Tursina Ratu ${ }^{5}$ \\ 1, 2, 3 Institut Agama Islam Negeri Bengkulu \\ Raden Fatah Street, Pagar Dewa, Bengkulu 38211, Indonesia \\ 4Mataram University \\ 5Samawa University \\ Coressponding Author. E-mail: \\ ${ }^{1}$ rohimin@iainbengkulu.ac.id \\ ${ }^{2}$ wiji@iainbengkulu.ac.id \\ 4 muhammaderfan@unram.ac.id \\ 5tursinaratu@universitas-samawa.ac.id
}

Received: June $15^{\text {th }}, 2020$

Accepted: July 27st, 2020

Online Published: July $27^{\text {th }}, 2020$

\begin{abstract}
Although many have raised the Inquiry learning model and the Number Head Together (NHT) learning model, there is no research on comparison of the two models in natural science subjects. This study aims to determine whether the learning outcomes of the 5th grade science students taught using the Inquiry Learning Model is better than using the Cooperative Learning Model Number Head Together (NHT) type in SDNegeri 66 Bengkulu City. This study used two groups, namely class 5A with 31 people as the experimental group and class 5B with 31 people as the control group. This research variable consists of independent variables namely Inquiry learning model and Number Head Together (NHT) learning model while the dependent variable is the science learning outcomes. This type of research is quantitative research with Nonequivalent Control Group Design approach. Data collection techniques using observation and multiple choice test questions. Data analysis techniques using the $t$ test. Based on the results of the study found in the posttest results of class 5A students who use Inquiry Learning Model in the medium and high categories as many as 31 students $(93 \%)$ get grades of 60 to 100 while the learning outcomes of class $5 \mathrm{~B}$ that use Cooperative Learning Models Type Number Head Together (NHT) as many as 31 students (81\%) get a value of 50 to 90 . It can also be proven by the results of the $t$ test calculation that is tcount of 4.352 and the value of the table for $\mathrm{df}=60$ with a significance level of $5 \%$ is 2,000 . From the analysis it was found that tcount is greater than ttable $(4.352>2,000)$. The results showed that the learning outcomes of Natural Sciences 5th grade students who were taught using the Inquiry Learning Model were better than using the Cooperative Learning Model Number Head Together (NHT) type at SDN 66 Kota Bengkulu.
\end{abstract}

Keywords: Learning Outcomes Inquiry Learning Model with Cooperative Learning Model Type Number Head Together (NHT)

\section{How to cite this article :}

Rohimin, R., Mukti, W. A. H., Oktaviani, S., Erfan, M., \& Ratu, T. (2020). Comparison of Learning Outcomes Inquiry Learning Model With Cooperative Learning Model Type Number Head Together (NHT) Learning In Natural Sciences Class V In State Elementary School 66 Bengkulu City. IJIS Edu : Indonesian Journal of Integrated Science Education, 2(2), 108-113. doi:http://dx.doi.org/10.29300/ijisedu.v2i2.3260 


\section{INTRODUCTION}

In the Big Indonesian Dictionary (KBBI), learning means "trying to gain intelligence or knowledge" (KBBI, 2016). As Allah Almighty says in surah Thaha verse 114 which means: Then Most High God is the true king, and do not be hasty in reading the Qur'an before being revealed to you, and say: "O my Lord, add to me knowledge ".

From the above verses it is fitting for humans to continue to study because science is a human endeavor to fulfill the need to gain knowledge or intelligence that they have not had before. Learning begins when humans are born (Indarti, 2019; Styawati \& Rizal, 2017; Suyono, 2011). Learning is interpreted as a process for obtaining motivation in knowledge, habitual skills and behavior. Besides learning as an effort to obtain knowledge or skills through instruction. The instructions in question are directions or guidance from educators or teachers. The process of learning, development and education is an event in everyday action (Dimyati \& Mudjiono, 1999). Education is meant here is the view that underlies all educational activities, both in the context of the preparation of role theory and implementation, and the administration of education, because education is a systematic conscious effort always starting from a number of certain principles. The foundation and principle are very important, because they are the pillars for the development of people and a particular nation's community. In addition, learning is an effort to obtain through instruction. Hangestiningsih, Zulfiati, \& Johan, (2015) furthermore, there are five categories studied by humans. That is:

1. Motor skills, which are skills that are shown from various body movements, such as writing, kicking a ball, clapping, running and jumping.

2. Verbal information, this information is strongly influenced by the ability of the student's brain, for example someone can understand something by speaking, writing, drawing, and others in the form of symbols that appear (verbal).

3. Intellectual abilities, in addition to using verbal symbols, humans are able to interact with the outside world through their intellectual abilities, for example being able to distinguish colors, shapes and sizes.

4. Cognitive strategies, internal organizational skills, which are indispensable for learning to remember and think. This cognitive ability is more demonstrated to the outside world, and cannot be learned in just one time requiring continuous improvement and practice.

5. Attitude, attitude is an important factor in learning because without this ability learning will not work well. The nature of a person in learning will greatly affect the results obtained from learning. Attitudes will greatly depend on his stance, personality and beliefs, cannot be learned or forced, but need full selfawareness (Susanti, 2016; Vennix, den Brok, $\&$ Taconis, 2018).

Therefore, education is a matter and a very important element in the formation of intelligent, creative, innovative and insightful human resources. RI Law Number 20 of 2003 concerning the National Education System requires education to be rooted in national culture and religious values based on Pancasila and the 1945 Constitution. Whereas education personnel are members of the community who are devoted to the administration of education.

Based on preliminary observations conducted by researchers at the 66th Elementary School of Bengkulu City on April 29, 2019 information was obtained that the low student learning outcomes, especially science subjects still had not reached KKM which is 70 . Researchers have seen a lot of efforts from the teachers in applying various learning models especially in Natural Sciences (IPA) subjects, such as Contextual Teaching and learning, a learning model that starts with oral questions and answers related to the real world of students and several other models such as Problem Based Learning to train and develop the ability to solve problems from the actual life of students and fun so students can think optimally. But there are still some obstacles, for example, constrained by books, time, costs, materials and practical tools, some students are difficult to control so students find it difficult to understand and because of this the students finally feel lazy to pay attention then finally they become chatting with friends or engrossed in playing and busy themselves.

Based on preliminary observations conducted by researchers at the State Elementary School 66 Bengkulu City on April 29, 2019 information was obtained that the low student learning outcomes, especially science lessons still had not reached KKM which is 70. Researchers have seen a lot of efforts from teachers in applying various learning models especially on Natural Sciences (IPA) subjects, such as Contextual Teaching and learning, a learning 
model that begins with oral questions and answers related to students' real world and several other models such as Problem Based Learning to train and develop the ability to solve problems from students' actual lives and be fun so that students can think optimally. But there are still some obstacles, for example constrained by books, time, costs, materials and practical tools, some students are difficult to control so students find it difficult to understand and because of this also the students finally feel lazy to pay attention then finally they become chatting with friends or engrossed in playing and busy themselves.

\section{METHOD}

This type of research that researchers do is quantitative research. Experimental research is based on the assumption of a single variable law and the existence of a method of difference, when the situation conditions are all the same in all respects, then one of these situations is added to one element, while the other situation is not added, the differences between the two situations This is due to the additional elements (Dewi, 2016; Effendi, Mursilah, \& Mujiono, 2018; Sugiyono, 2007; Zai, 2019).

With this type of control group design, both the experimental group and the control group were compared, although the group was selected and placed without randomization (randomization). The research design that the author uses in this study is

This research was conducted at 66 State Elementary School Bengkulu City on May 6 to June 24, 2019 while the subjects applied with the Inquiry Learning Model and the Number Head Together Learning Model (NHT) were Natural Science (IPA) subjects.

Population and Research Samples 1. Population

Researchers determined the study population were all 66 elementary school students in Bengkulu City. While the target population in this study are VA and VB classes.

2. Samples

Samples are members of the target population taken using certain techniques. The sample in this study is the VA class of 31 people and VB 31 people in SD Negeri 66 Bengkulu City. The sampling technique in this study is total sampling (the entire target population is the study sample).
In general, data collection techniques that can be used by researchers in quantitative research are:

1. Observation, is a way to collect information material carried out by conducting observations and recording systematically against the phenomena that are being targeted by observations.

2. Documentation, is intended to obtain data directly from the research site, including relevant books, regulations, activity reports, photographs, documentary films and research relevant data.

3. The test used in this study is a written test in the form of multiple choice questions of 20 questions. This test is used to obtain data on the level of application of student learning concepts to the material being taught. This study uses a test method to collect data about students' conceptual abilities on the subject of Changes in Objects. There are two types of tests, namely the pretest and posttest given to this study sample. Pretest is a test that is conducted before the teaching and learning process begins, while posttest is a test conducted after the learning process is complete.

4. The author gives a pretest for the control class and the experimental class as a research sample, before conducting a teaching experiment to the experimental class. That was done to measure the ability to apply the concepts of science subjects to students before the experiment. In the end, posstest was given to the sample after the experiment was carried out.

Data Collection Instruments

1. Definition of Variable Operations

a) The Inquiry Learning Model is a series of learning activities that emphasizes the process of thinking critically and analytically to seek and find answers to a problem in question for themselves.

b) Number Head Together Learning Model is one type of cooperative learning.

c) Natural Sciences (IPA) or now known Science is one branch of science that was developed based on the results of experiments.

2. Instrument louvers Instruments used to collect data using instruments in the form of tests in the form of questions about the material 
about changing the shape of objects. The steps for making the test consist of:

a) Determine the form of test questions to be made.

b) Make a grid of test questions.

Data Validity and Reliability Techniques

1. Test Validity

In this research instrument, content validity testing was done by asking for expert judgment.

2. Reliability Test

Reliability is an index that shows the extent to which a measuring instrument can be trusted or relied upon. Reliability indicates the stability or consistency of the measurement results.

Data analysis technique

1. Prerequisite Test

To conduct prerequisite tests, the writer here uses the normality test and homogeneity test.

a) Data Normality Test, normality test is performed to determine whether the sample under study is normally distributed or not.

b) Homogeneity Test

After knowing the research data are normally distributed, then homogeneity testing is then performed. Homogeneity test functions whether the two population groups are homogeneous or heterogeneous. What is meant by the homogeneity test here is to test whether or not the variations of two or more distributions are equal. Homogeneity test used in this study is the fisher test.

2. Analysis Techniques

After conducting the prerequisite test that is the normality test and homogeneity test, then the next is the research hypothesis test to find out whether the learning outcomes of the 5 th grade students taught by Inquiry Learning Model is better than using the Number Head Together Learning Model in SDN 66 Kota Bengkulu, the t-formula parametric tests but first classifying and tabulating according to their respective variables, namely: Variable $\mathrm{x}$ (independent variable), namely Inquiry Learning Model is better than using the Learning Model Number Head Together
Variable y (dependent variable), namely learning outcomes.

The analysis technique used is the following analysis. To test the comparison of ratio or interval data, the results of tests that have been conducted by researchers in the experimental class and the control class use the t-test formula.

For comparative testing is to test the ability of generalization (the significance of the results of research in the form of a match state variable from two sample averages).

\section{RESULTS AND DISCUSSION}

This study uses an experimental method, which places research subjects into two groups which are divided into experimental class categories, namely the Inquiry Learning Model and the control group, namely the Number Head Together Learning Model. From the results of tests that have been carried out obtained the following results:

1. Out of 31 fifth grade students taught by the Inquiry Learning Model the value of science learning outcomes is $(93 \%)$ with an average of 93.

2. Out of 31 fifth grade students taught with the Number Head Together Learning Model, the value of science learning outcomes is $81 \%$ with an average of 81 .

3. Furthermore, to test the working hypothesis proposed by the author in the research that there are natural science learning outcomes with Inquiry Learning Model better than Number Head Together in fifth grade students of SD Negeri 66 Bengkulu City will use the formula " $t$ " test then Ha is accepted and Ho is rejected. So that the working hypothesis that the authors propose about there is a science learning outcomes with Inquiry Learning Model better than Number Head Together with a value $(93 \%>81 \%)$ in fifth grade students of SD Negeri 66 Bengkulu City can be accepted and useful for all.

\section{CONCLUSION}

Based on the results of research conducted by the author can be concluded that there are differences in learning outcomes between uses. The Inquiry and Number Head Together 
Learning Model towards the learning outcomes of 5th grade students of SDN 66 Bengkulu City. Can be seen from the results of the hypothesis by using the " $t$ " test on the two groups with the results obtained, tcount $=4.352$ while ttable with df 60 at a significant level of $5 \%$ ie 2,000 . Thus tcount $>$ ttable $(4,352>2,000)$ which means the working hypothesis $(\mathrm{Ha})$ in this study was accepted, namely the learning outcomes of the 5th grade science students taught by using the Inquiry Learning Model is better than the students taught by using the Number Head Together Learning Model in SDN 66 Bengkulu City. Evidenced by the average value of the science learning outcomes Posttest grade $5 \mathrm{~A}$ is higher than grade $5 \mathrm{~B}$, which is Posstest $93 \%>$ Posstest $81 \%$.

\section{REFERENCE}

Dewi, P. S. (2016). Kemampuan Proses Sains Siswa Melalui Pendekatan Saintifik Dalam Pembelajaran IPA Terpadu Pada Tema Global Warming. EDUSAINS, 8(1). https://doi.org/10.15408/es.v8i1.1564

Dimyati, \& Mudjiono. (1999). Belajar dan Pembelajaran. Jakarta: Depdikbud PT. Rineka Cipta.

Effendi, E., Mursilah, M., \& Mujiono, M. (2018). Korelasi Tingkat Perhatian Orang Tua dan Kemandirian Belajar dengan Prestasi Belajar Siswa. Titian Ilmu: Jurnal Ilmiah Multi Sciences, 10(1), 17-23. https://doi.org/10.30599/jti.v10i1.131

Hangestiningsih, E., Zulfiati, H. M., \& Johan, A. B. (2015). Pengantar Ilmu Pendidikan. Diktat Pengantar Ilmu Pendidikan. https://doi.org/http:/ / dx.doi.org/10.101 6/j.msec.2016.03.021

Indarti, S. (2019). Investigasi Implementasi Model Discovery Learning Berbasis Pendekatan Saintifik Dalam Meningkatkan Aktivitas dan Hasil Belajar IPA. IJIS Edu: Indonesian Journal of Integrated Science Education, $\quad 100$. https:/ / doi.org/10.29300/ijisedu.v1i2.22

44

KBBI. (2016). Kamus Besar Bahasa Indonesia ( KBBI ). Kementerian Pendidikan Dan Budaya.

Styawati, P. S., \& Rizal, S. (2017). Teaching Reading Comprehension Through Snowball Throwing Teaching Technique. At-Ta'lim : Media Informasi Pendidikan Islam, 13(2), 275-300. Retrieved from http:/ / ejournal.iainbengkulu.ac.id/index. $\mathrm{php} /$ attalim/article/view / 558

Sugiyono. (2007). Metode Penelitian Kualitatif, Kuantitatif dan R\&D. Bandung: Alfabeta.

Susanti, A. (2016). Penanaman Nilai-Nilai Tasawuf dalam Pembinaan Akhlak. AlTadrkiyyah: Jurnal Pendidikan Islam, 7(2), 277-298.

Suyono, H. (2011). Belajar dan pembelajaran Teori dan konsep Dasar. Bandung: PT Remaja Rosdakarya.

Vennix, J., den Brok, P., \& Taconis, R. (2018). Do outreach activities in secondary STEM education motivate students and improve their attitudes towards STEM? International Journal of Science Education, 40(11), 12631283.

https:/ / doi.org/10.1080/09500693.2018. 1473659

Zai, J. (2019). Pengukuran Tingkat Keterampilan Proses Sains Mahasiswa pada Praktikum Gaya Gerak Listrik Induksi di Laboratorium Fisika Dasar Universitas Ahmad Dahlan Yogyakarta. Jupiter : Jurnal Pendidikan Teknik Elektro, 04(1), 1-6. 